\title{
JUGOSLOVANSKA NAIVA IN POPULARNA KULTURA
}

Ključne besede: jugoslovanska naivna umetnost, popularna kultura, Tabor likovnih samorastnikov Trebnje, Jugoslavija, ideologija

\section{Kam s to naivo?}

Številni iz generacij, rojenih v štiridesetih in petdesetih, pa tudi v zgodnjih šestdesetih letih, ne glede na izobrazbo, družbeni položaj ali spol dobro poznajo naivno slikarstvo ali vsaj njegove najbolj znane predstavnike, če že niso lastniki likovnih del ali reprodukcij oziroma celo likovni ustvarjalci. Mlajšim generacijam pa je ta likovni pojav dokaj neznan in nezanimiv. Obiskovalci, pripadniki starejših generacij, ki obiščejo Galerijo likovnih samorastnikov v Trebnjem, se $\mathrm{z}$ navdušenjem sprehodijo po stalni postavitvi zbirke in se z žarom spominjajo živahnega kulturnega in družabnega dogajanja, povezanega $\mathrm{z}$ naivo, saj jih čas, ko je bila naiva $\mathrm{v}$ poznih šestdesetih, sedemdesetih in zgodnjih osemdesetih letih na višku svoje priljubljenosti, spomni na njihovo mladost oziroma odraslo obdobje ter določeno mero splošne blaginje, ki je takrat vladala v Jugoslaviji. Hkrati jadikujejo, kako današnje umetnosti ne razumejo in jo doživljajo kot prazno in puhlo ter se sprašujejo, zakaj ni več figuralnega, s fantazijo in folkloro prepletenega »naivnega « ustvarjanja.

Meni je bila naivna umetnost le bežno znana, in sicer zaradi knjige $\check{C} u$ dovita Jugoslavija, v kateri imajo svoje poglavje hlebinski slikarji. Velikih lesenih kipov, ki so nekoč stali pred župniščem v Trebnjem, nikoli nisem povezala s to likovno zvrstjo, prav tako se ne spomnim, da bi v času štu- 
dija umetnostne zgodovine Carinika (Henryja Rousseauja) prav posebej izpostavili kot začetnika naivne umetnosti. Z njo sem se seznanila šele $s$ polletnim delom $v$ Galeriji likovnih samorastnikov Trebnje. $Z$ urejanjem in proučevanjem dokumentacije ter zbirke, s pogovori z zaposlenimi, organizatorji tabora ter nekaterimi Trebanjci in likovniki sem se zasilno poučila, kaj naj bi bila naivna umetnost, saj se mi je z odgovori porajalo toliko več vprašanj. Priznam, bolj kot likovna zbirka me je pritegnil mednarodni tabor kot kulturni in družabni dogodek, ki sem ga spoznavala v praksi in skozi pripovedovanja ljudi, časopisne članke in fotografije, na katerih so bile ujete številne ugledne in znane osebnosti iz jugoslovanskega in slovenskega političnega, kulturnega in gospodarskega okolja. $V$ tednu, ko je potekal tabor, je Trebnje postalo, morda nekoliko pretirano, Meka za veliko tujih in domačih, preprostih in izobraženih ljudi, željnih posrednega ali neposrednega likovnega in kulturnega udejstvovanja. Čudila sem se, kako je lahko dokaj marginalen likovni fenomen, kot je bila naiva, sprožil številna, tudi mednarodna kulturna in družabna dogajanja $\mathrm{v}$ Jugoslaviji ter gostovanja $\mathrm{v}$ tujini, katerih del je bil trebanjski tabor. Hkrati je imel ta fenomen trdno politično in posredno tudi finančno podporo, obenem pa je doživel skorajda divjo komercializacijo. Prav tako me je čudilo, da sta od druge polovice devetdesetih let (govorim za Slovenijo) naiva in tabor kljub širši prepoznavnosti in popularnosti postopoma padala $\mathrm{v}$ pozabo. Tudi med samimi Trebanjci igra tabor, ki od svojega začetka leta 1968 redno poteka vsako leto, v kulturnem dogajanju občine vedno bolj postransko vlogo. ${ }^{1}$

Množičnost in popularnost naive v preteklosti je v meni sprožila vprašanje, ali lahko jugoslovansko naivo postavim v kontekst popularne kulture in kako sta lahko hodili tako rekoč $\mathrm{z}$ roko v roki ideologija socialističnega samoupravljanja in totalna komercializacija likovnega pojava. Na vprašanja skušam odgovoriti skozi prizmo trebanjskega tabora. Preden pa se lotim razlage in interpretacij, je treba razložiti, kaj je naiva in kaj razumemo kot popularno kulturo.

1 Z zaposlitvijo strokovnega kadra leta 2008 galerija $\mathrm{z}$ rednim razstavnim in spremljevalnim programom $\mathrm{v}$ trebanjskem kulturnem dogajanju ponovno pridobiva na pomenu. Tako lahko upamo, da bo kmalu prišlo do strokovnega in kritičnega ovrednotenja zbirke in naivne umetnosti na Slovenskem. 
Pojem naivne umetnosti je tako izmuzljiv kot pojem popularna kultura, zato obema namenjam posebno poglavje. $V$ najširšem kontekstu je naivna umetnost likovno ustvarjanje avtorjev brez formalnega in sistematičnega likovnega šolanja, ki v poenostavljeni formi sledijo figuraliki in pripovednosti. Ti likovniki pogosto prihajajo iz marginalnih družbenih, kulturnih in geografskih okolij, kljub temu pa jim s pomočjo talenta in pozornosti posameznikov uspe oblikovati svoj prepoznavni likovni izraz in stopiti iz anonimnosti. Naivni umetniki so bili sopotniki moderne umetnosti; nekateri mojstri so uvrščeni v umetnostnozgodovinske preglede 20. stoletja. Pomemben delež k prepoznavnosti in popularnosti naivne umetnosti je prispevala jugoslovanska naiva, predvsem hlebinski slikarji s številnimi razstavami in publikacijami doma in $\mathrm{v}$ tujini. Mednarodni sloves in prepoznavnost domačih naivcev v tujini je bil eden od pomembnih izvoznih kulturnih artiklov kot tudi primerna promocijska podoba jugoslovanske države. Poleg tega pa je bil fenomen kmečkih slikarjev oziroma hlebinska šola pisan na kožo socialističnemu režimu, ki je skušal afirmirati ideologijo, da umetnost ni domena elit, temveč pripada vsem in je prav tako lahko vsem razumljiva. $Z$ njo se lahko ukvarjajo tudi ljudje s periferije brez splošne ali formalne likovne izobrazbe, ki celo dosežejo mednarodno slavo.

Začetki naive segajo $\mathrm{v}$ čas historičnih avantgardnih gibanj in krog leve politične opcije. Po drugi svetovni vojni je avantgarda izgubila svoj uporniški in družbeno angažirani naboj ter v kapitalističnih državah postala žrtev popularne kulture, v socializmu pa je bila ukinjena že pred vojno. Tudi v Jugoslaviji se je socialno angažirana nota likovne vsebine naive izgubila in je v času razcveta začela ponavljati dekorativne oblike ponavljajočih se pastoralnih motivov in fantazijskih krajin, ki so jih gojili številni t. i. naivni umetniki. Reproduciranje likovnih vzorcev in vsebin, medijska promocija ter številni kulturni spektakli, povezani z naivo, so popularizirali in homogenizirali splošni okus ter estetsko obzorje. Vse to kaže na značilnosti, ki jih pripisujemo popularni kulturi.

Pri izbiri rabe terminov množična ali popularna kultura sem se odločila za slednjo in se pri tem naslanjam na podobno odločitev Rajka Muršiča. Z uporabo termina množična kultura je namreč označil sodobno kulturo, ki jo zaznamuje možnost neskončne reprodukcije kulturnih dobrin (Muršič, 2000, 22). Poleg tega je množična kultura posredovana predvsem skozi množične 
medije. Res so mediji, h katerim lahko štejemo tudi muzeje in galerije (glej Huyssen, 1995), pripomogli k prepoznavnosti in popularnosti naive, vendar je niso ustvarili, kakor se to dogaja z množično kulturo danes. Poleg tega je popularna kultura bliže ljudski, torej neelitni kulturi. Nosilci naivne umetnosti v Jugoslaviji, na primer hlebinski slikarji, so izhajali še iz zadnjih prežitkov ljudske kulture, saj sta industrializacija in urbanizacija le počasi prodirali v ruralna zakotja. Po vojni pa je naiva s pomočjo politične direktive širjenja množične kulturno-umetniške ustvarjalnosti in medijskega populariziranja postala del najširših množic, ki so predstavljale neelitno kulturo.

$\mathrm{Na}$ Slovenskem se je $\mathrm{z}$ naivno umetnostjo strokovno ukvarjalo bore malo umetnostnih zgodovinarjev, saj je širša stroka ni jemala resno in jo je prištevala $\mathrm{k}$ amaterizmu $\mathrm{z}$ omejeno estetsko in umetniško vrednostjo. Večina besedil in člankov je nastala $\mathrm{v}$ okviru trebanjske institucije in njenih dogodkov. Najpogostejša pisca sta (bila) Zoran Kržišnik in Mirko Juteršek. Poleg njiju so se nezorane ledine lotili še: leta 1966 Tomaž Brejc, ki je podal načelen razmislek o naivnem slikarstvu (Za naivno slikarstvo: Tisnikar in Jaki; po Komelj, 2006, 122), Marjan Tršar ob razmišljanju o koroških slikarjih Antonu Repniku in Jožetu Tisnikarju ${ }^{2}$ (Kriteriji za presojo umetniške kvalitete "samorastnikov" in Tisnikar) ter Milena Režun (Ali so slovenski naivci res naivni?). Dilema se je pojavila že v samem poimenovanju tega likovnega pojava na Slovenskem, saj moramo, kakor je v pogovoru dejal Mirko Juteršek, v našem prostoru takšno likovno ustvarjanje imenovati "samorastništvo«, medtem ko se drugod po bivši Jugoslaviji imenuje naiva. Po njegovem mnenju gre razloge iskati v nosilcih te likovne zvrsti, ki so bili v materialno razvitejšem slovenskem okolju delavci, obrtniki, učitelji in upokojenci, medtem ko so bili drugod po Jugoslaviji, zlasti v Podravini, Vojvodini in Bosni, ustvarjalci kmetje. To načeloma drži za prve generacije naivcev, pozneje pa se je ta slika specifike družbenega sloja ustvarjalcev močno spremenila, saj imajo likovniki poklicno, srednjo in celo univerzitetno izobrazbo; veliko jih živi v mestih in ne na zakotnih kmetijah. Juteršek »samorastnika« razume kot akademsko neizšolanega umetnika, ki se

2 Jožeta Tisnikarja ne moremo uvrščati v krog slovenske ali jugoslovanske naivne umetnosti, saj je s svojo likovno ter vsebinsko izpovednostjo in ustvarjalnostjo močno izstopal iz njenega konteksta. Tudi sam se ni nikoli prišteval k tej likovni zvrsti. Kot samouki umetnik pa je pritegnil pisce, ki so se ukvarjali z naivo. 
nanaša na določeno likovno smer, za katero je bistvena njena povezanost z izročilom ter uveljavljenimi in globoko ukoreninjenimi vizualnimi spoznanji najširših množic (po Štepec, 1997, 11). Po Tršarjevem mnenju se je pojem »samorastništvo « uveljavil zato, ker je imel bolj pozitiven zven kot morda bolj negativna pojma »naivci« ali »primitivci« $(1970,84)$. Zoran Kržišnik je menil, da gre pri »samorastništvu« za izpovedno slikarstvo, ki nima razvoja. Zanj je značilno figurativno, predmetno ustvarjanje, ki ima izrazito izpovedno in pripovedno noto (po Štepec, 1997, 11). Ker pa gre po mojem mnenju za splošnejše gledanje, Kržišnik verjetno ni imel pred očmi le »slovenskega samorastništva «, temveč širše ustvarjanje v okviru naivne likovne zvrsti. Teoretičnega razglabljanja o tem, kaj je »samorastniško« ustvarjanje, se je še najbolj resno lotil Marjan Tršar, ki ga je definiral v opoziciji do amaterizma, akademizma in ljudske umetnosti (tako kot že hrvaški kolegi pred njim). Skušal je definirati ključne slogovne elemente, ki jih je videl v prepletu posebne vrste realizma, ekspresivnosti in simbolike. Vse to pa je prepleteno $\mathrm{z}$ dekorativnostjo, ki je folklorno obarvana (1970, 84-87). Tudi Milena Režun vidi razliko med slovenskim »samorastništvom « ter jugoslovansko naivo, in sicer v vsebini in likovnem načinu njenega podajanja $(1991,287)$. Dušan Štepec je v seminarski nalogi Tabor Likovnih samorastnikov $v$ Trebnjem iz leta 1997 prikazal pregled razvoja in poimenovanja naive pri nas, $\mathrm{v}$ Jugoslaviji in $\mathrm{v}$ svetu. Naloga je prva resna in pregledna študija o taboru in slovenski naivi sploh. Zaključi jo $\mathrm{z}$ mnenjem, da ne vidi ne likovnih ne vsebinskih razlik med slovenskim »samorastništvom « in jugoslovansko naivo, ki so jo skušali postaviti zgoraj omenjeni avtorji (Štepec, 1997, 41). Poleg tega razume pod pojmom naivna umetnost likovno ustvarjanje ljudi, ki spadajo v okvir amaterizma $(1997,40)$. Štepčev prispevek je nadgradil in postavil $\mathrm{v}$ širši umetnostnozgodovinski in družbeno-politični kontekst Miklavž Komelj v članku Galerija likovnih samorastnikov Trebnje iz leta 2006. Zanj je historične naive kot likovnega pojava konec. Tako negira Kržišnikovo tezo o likovni ustvarjalnosti brez razvoja. ${ }^{3}$ Poleg tega izpostavi zbirko kot izredno zanimivo likovno dediščino, ki je nujno potrebna strokovnega ovrednotenja in analize $(2006,133)$. Knjiga Galerija Likovnih samorastnikov Trebnje, ki je izšla leta 2007 ob 40-letnici

3 Ta misel se žal reproducira na zloženki Galerije likovnih samorastnikov Trebnje in nadaljuje ustvarjanje lažnega mita, nakaže pa tudi na nestrokovnost in nekritičnost galerije. 
tabora, je prvi pregleden primer predstavitve delovanja taborov in galerije ter avtorjev in njihovih del, ki jih hrani galerija. Nekatera spremljajoča besedila, sicer nekoliko predelana, so bila objavljena že prej in sem se jih že dotaknila (Dušan Štepec, Razvoj Tabora likovnih samorastnikov od njegovega začetka do danes), druga pa podajo bolj kot ne zgodovinsko-kronološki razvoj tabora in galerije (Janez Gartnar, Predgovor, in Mirko Juteršek, $V$ razmislek ob jubileju) ali pa so reciklaža besedil iz predhodnih razstavnih katalogov galerije (Zoran Kržišnik, Trebnje - 40 let). Zato žal ne ponujajo nobene nove analize, interpretacije ali ovrednotenja zbirke.

Pri tako skromni umetnostnozgodovinski predstavitvi in analizi naive na Slovenskem je težko pričakovati še kakšno sociološko ali kulturnoantropološko analizo te problematike.

Zaradi očitnega pomanjkanja strokovne, še bolj pa znanstvene analize naivne umetnosti v slovenski literaturi in zaradi njenega ohlapnega in po mojem mnenju pavšalnega definiranja sem se pri opredelitvi pomena in razvoja tega likovnega pojava naslonila na hrvaške avtorje. Ti se fenomenu znanstveno in strokovno zvesto posvečajo ter so tudi mednarodno referenčni avtorji.

\section{Naivna umetnost in njen razvoj v socialistični Jugoslaviji}

Kaj je t. i. naivna umetnost in kako jo definirati, je bilo vprašanje, ki je burilo likovne teoretike in na sploh ljudi, ki so se s tem fenomenom ukvarjali vse od njegovega pojava v Franciji in poznejših »odkritij« drugod po svetu. Ustvarjanje samoukih slikarjev in kiparjev, ki so s svojim svojevrstnim likovnim izrazom vzbudili zanimanje ustvarjalcev moderne umetnosti, zbiralcev, publicistov ter likovnih kritikov, je imelo več imen: nagonska umetnost, neoprimitivna umetnost, marginalna umetnost, insitna ${ }^{4}$ umetnost,

4 Insita izhaja iz latinske fraze in situ, ki pomeni na mestu izvora. To ime so predlagali ustanovitelji trienala naivne umetnosti v Bratislavi, prvič prirejenega leta 1966. S tem izrazom so skušali definirati naivno umetnost in sorodne pojave samoukega ustvarjanja. Prav primer tega trienala pa kaže na še vedno dokaj dvoumno in izmuzljivo poimenovanje tega likov- 
včasih tudi Outsider art. Sami slikarji so dobili ime tudi po svojih razstavah (na primer slikarji Svetega srca), ${ }^{5}$ časovnem okviru slikanja (nedeljski slikarji) oziroma po družbenem statusu ( $k m e c ̌ k i ~ s l i k a r j i) .{ }^{6}$ Vsa ta imena kažejo na določeno zmedo in heterogenost $\mathrm{v}$ pojmovanju pojava likovnega ustvarjanja različnih formalno nešolanih posameznikov, pa naj prihajajo iz perifernega okolja (vasi ali mesta) ali so celo psihično ali fizično hendikepirani (njihova dela prištevamo v Art brut, Raw Art ali celo Outsider Art). Kmalu sta likovna kritika in teorija ugotovili, da se ne da tlačiti vsega v en koš in da gre pri pojmih Art brut in naivna umetnost za različne likovne forme in koncepte, ki pa imajo nekaj stičnih točk (Crnković, 2002b, 179). Poleg tega se ta različna našteta poimenovanja še dodatno razlikujejo glede na posamezne države. Če bi skušali to ustvarjanje spraviti na skupni imenovalec, bi ga lahko definirali kot slikarstvo in kiparstvo samoukih umetnikov ali umetnikov, ki niso bili deležni formalnega šolanja ter so živeli v marginalnih socialnih in kulturnih razmerah. Njihov izraz razumemo kot ljudsko in spontano kreativnost, ki dosega visoko estetsko vrednost in ki vsekakor ni amatersko ustvarjanje (Poli, 2002, 182; Crnković, 2002b, 197). Pod to definicijo se je oblikovalo predvsem razumevanje pojma naivna umetnost, ki se je uveljavil v petdesetih letih 20. stoletja, ko je mogoče slediti vse bolj številnim nacionalnim in mednarodnim razstavam, večjezičnim monografijam in publikacijam ter razpravam, simpozijem ter javnim in zasebnim zbirkam. Vendar pa o naivni umetnosti ni mogoče govoriti kot o likovnem gibanju ali tendenci oziroma šoli, razen morda v primeru hlebinske šole. Mednarodni uspeh, ki so ga dosegli njeni najvidnejši predstavniki, je v Jugoslaviji sprožil plaz amaterskih slikarjev in velikega zanimanja za ta tip umetnosti, kar je posledično od šestdesetih let dalje pridalo naivi pretirano

nega pojava. Poleg naivne umetnosti so na teh trienalih prikazovali še ljudsko umetnost, umetnost neevropskih narodov, amaterske umetnike, Art brut in Outsider art. Tako se Vladimir Crnković sprašuje, ali je namen tega trienala prikazovati resnično likovno kakovost formalno nešolanih likovnikov ali gre za zgolj prikazovanje različnih oblik samoukih likovnih praks, ki so pogosto pod mejo umetniške vrednosti (2002b, 179-198).

5 Poimenovani po razstavi Les peintures du coeur du sacré v galeriji Galerie des Quatre-Chemins v Parizu leta 1928, kjer so se prvič samostojno predstavili francoski naivni slikarji oziroma moderni primitivci, kot so jih tedaj poimenovali (Henry Rousseau, André Bauchant, Camille Bombois, Séraphin Louis in Louis Vivin) (Crnković, 2002a, 217-218).

6 To se navezuje predvsem na slikarje hlebinskega kroga. 
komercialni razmah. Prav fenomen hlebinske šole je zadnja faza evropske historične naivne umetnosti (Poli, 2002, 182).

Govor o določenem skupinskem fenomenu oziroma likovnem slogu ni mogoč zaradi velike geografske, družbene in kulturne raznolikosti ter konteksta, v katerem so dela nastajala, pa tudi zato, ker so resnični in najbolj nadarjeni naivci svojo nadarjenost razvili v močno individualno noto, $\mathrm{z}$ originalnostjo, neodvisnostjo in prepoznavnostjo ter estetsko vrednostjo (Poli, 2002, 182-183; Zander, 2002, 184-186). Prav zato jih pojmujemo kot resnične umetnike in jih uvrščamo v kontekst moderne umetnosti (Depolo, 2001a, 31; 2001b, 27, 40, 115; Gamulin, 1999, 78).

Teorija naivne umetnosti sloni na poskusu spraviti na skupni imenovalec različne forme in motive samouškega slikarstva ter na razlikovanju od ljudskega, amaterskega in profesionalnega ustvarjanja. Zaradi fantastičnih podob rastlinskega in živalskega sveta ter prevladujoče pastoralne motivike so jo pogosto enačili z nedoločenim spontanim ljudskim vrenjem oziroma $\mathrm{z}$ idealizirano podobo ljudskega življenja predindustrijske dobe in s tem ljudske umetnosti. Vendar je razkorak v kontinuiteti med kulturno evalvacijo ljudske umetnosti in tistimi umetniki, ki so protagonisti naive, velik. Prva je pogosto anonimna, njen izraz izvira iz tradicije ter prenosa znanj in izkušenj iz generacije v generacijo, je nosilka določenih vrednot in ohranja določene kolektivne predstave. Prav tako je omejena na lokalno skupnost določenega družbenega sloja. Druga, tj. naivna umetnost, je predvsem individualna izkušnja ter izraz doživljanja lastnega okolja in domišljije (Poli, 2002, 182; Zander, 2002, 184). Nezanemarljiv je tudi prispevek sugestivne pomoči šolanih umetnikov, likovnih kritikov in zbiralcev ter galerijskih institucij, ki so ga bili deležni talentirani samouki (Crnković, 2002a, 217-218; 2002b, 70-84). Amaterski likovni ustvarjalci pogosto sledijo sodobnim likovnim slogom in poskušajo posnemati akademsko umetnost, katere predstavniki so sistematično šolani umetniki, dobro podkovani v likovnih tehnikah; pogosto so nosilci določenega intelektualnega, idejnega in slogovnega programa (Gamulin, 1999, 73-117).

Poudariti pa je treba, da se v kontekstu naivne umetnosti dosledno sledi figuraliki in narativnosti, torej širši publiki lažje razumljivim formam in vsebinam. 
Korenine in razvoj naivne umetnosti segajo v Francijo, v čas vzpona mednarodnega avantgardnega gibanja konec 19. stoletja. Zanj je značilno navdušenje nad različnimi oblikami kreativnega izraza, ki so radikalno nastopale proti kanonu tedaj uradne umetniške prakse in dominantnemu meščanskemu okusu (Poli, 2002, 183; Zander, 2002, 185). Klasiki francoske naive (Henry Rousseau, André Bauchant, Camille Bombois, Séraphin Louis in Louis Vivin), poimenovani moderni primitivci, so prvič skupaj razstavljali v Parizu leta 1928. Razstavo je pripravil zbiralec umetnin Wilhelm Uhde. Bil je njihov prijatelj in mentor, ki jih je spodbujal in usmerjal pri ustvarjanju. Njemu gre tudi zasluga za populariziranje umetnikov, kot so Pablo Picasso, Georges Braque, André Derain in Raul Dufy, ter že omenjenih modernih primitivcev, o katerih je prvi pisal likovne kritike in pozneje monografije (Crnković, 2002a, 217-218). Modernemu umetniškemu gibanju, ki je iskalo nov likovni izraz, zanemarjajoč zakonitosti perspektive, klasične modelacije, proporcionalnosti in doslednega posnemanja realnosti, so pripadali tudi moderni primitivci. Vendar so se od modernistov razlikovali po tem, da se, ko so enkrat osvojili svoj osebni slog, od njega niso oddaljevali. Res so morda slikali bolj "nagonsko« kot premišljeno, torej brez nekega intelektualnega programa ali manifesta (zato so jim pripisovali "neznanje« ali celo spontanost), vendar je bil prav to tudi njihov namen, torej je bilo likovno snovanje kljub vsemu premišljeno (Crnković, 2002a, 222-223).

Če na kratko povzamem pojmovanje naivne umetnosti Miklavža Komelja, gre za zgodovinski pojav, ki je nastal šele iz srečanja med arhaično učinkujočimi elementi »ljudskega « izročila, občutljivostjo industrijske družbe in modernizmom, pri čemer je prihajalo do zanimivih interakcij; $v$ odnosu do modernistične senzibilnosti naiva ni bila samo objekt, nad katerim so se modernisti navduševali v kontekstu splošne fascinacije s "primitivizmi«, ampak so začetniki naivnega slikarstva srečanje z modernizmom na različne načine vpisovali v lastno produkcijo $(2007,123)$.

Za začetek naive na jugoslovanskih tleh štejemo pojav hlebinske šole na Hrvaškem, ki je bil vezan na avantgardni tok v kontekstu tedanje hrvaške levičarsko obarvane socialnokritične umetnosti in na perspektivo razrednega boja. Hlebinski kmečki slikarji (Ivan Generalić, Franjo Mraz, Mirko Virus) so se javnosti prvič predstavili, ko so bili vključeni v umetniško- 
družbene dejavnosti skupine Zemlja, ki je delovala v prvi polovici tridesetih let. Ta je odigrala vlogo hrvaške avantgarde par excellence, kakor se je izrazil Depolo (2001b, 44). Predstavniki skupine Zemlja so hoteli prikazati, da likovna nadarjenost in izraznost ni povezana $\mathrm{z}$ določenim družbenim slojem in razredom. S predstavitvijo dejavnosti najširših množic, $v$ danem primeru kmetov, so hoteli iniciatorji pokazati, kako in koliko lahko »avtentični « predstavniki »naroda « brez širše izobrazbe skozi umetnost spregovorijo o sebi in o svojem družbenem položaju. Vendar je treba poudariti in razložiti, da je hlebinska šola neke vrste invencija akademskega slikarja in člana Zemlje Krsta Hegedušića. Med študijem v Parizu so ga prevzele politične in družbene ideje avantgarde in njene pojavne oblike. V iskanju pristnega in avtentičnega ljudskega (hrvaškega) izraza, ki bi služil narodu in ga izobraževal ter tako posredno izboljšal njegov socialni, ekonomski in kulturni položaj, je Hegedušić odkril mlade slikarje v Hlebinah, rojstni vasi svojega očeta. Ti so prerisovali razglednice in drug slikovni material, ${ }^{7}$ ki jim je bil na voljo. Hegedušić se je za te naturščike zavzel, jih učil risati in jim svetoval, katere motive, forme in tehnike naj uporabljajo. Vse to je počel v želji, da bi bile slike kmečkih slikarjev kar najbolj avtentične in izraz »naše stvarnosti« (Crnković, 2006, 8-9; Depolo, 2001a, 42-46). Hegedušić je spodbujal tudi slikanje na steklo, saj je menil, da je to pristna tehnika ljudske ali kmečke umetnosti. To tehniko so mojstri jugoslovanske naive razvili do popolnosti.

Zaradi socialne angažiranosti je bila skupina Zemlja prepovedana. Hegedušić je v skladu s svojo socialno ideologijo naivce iskal ne le med kmeti, temveč tudi med delavci, pri katerih pa je bil manj uspešen (Crnković, 2006, 10).

Po drugi svetovni vojni je Ivan Generalić, najvidnejši predstavnik hlebinske šole, postal neke vrste slikarski guru in učil slikati mlajše generacije v Podravini (postal je tudi vaški učitelj). Sam ni bil tako socialno angažiran kot Mraz ali Virus, ki sta sodelovala v NOB, temveč se je nagibal bolj k ideji larpurlartizma (Crnković, 2006, 13), kar sicer ni vplivalo na njegovo slikarsko kakovost, je pa verjetno kljub vsemu v določeni meri vplivalo na

7 Vladimir Crnković mi je povedal, da jim je v roke prišel tudi almanah Die Bleue Reiter. Pogovor 18.4.2008 v Hrvaškem muzeju naivne umetnosti, Zagreb. 
vsesplošno dekorativnost, ki se je razpasla pri mlajših generacijah. Zelo odmevna prva samostojna razstava (pozneje se jih je tako doma kot v tujini zvrstilo še kar nekaj) Ivana Generalića v Parizu leta 1953 je imela velik vpliv doma v Hlebinah in tudi drugod po Jugoslaviji. Vse več kmečkih, delavskih in drugih amaterskih slikarjev se je začelo resno ukvarjati s slikarstvom, pogosto v maniri »hlebinske forme in vsebine«, kar je pripeljalo do množičnosti produkcije in reprodukcije naivnega likovnega izraza ali hotenja, prav tako pa tudi do njenega zatona. Crnković vidi, morda nekoliko radikalno, konec naive prav z objavo Enciklopedije naivne umetnosti sveta avtorja Ota Bihalj-Merina leta 1984, saj je s predstavitvijo velikega števila raznovrstnih avtorjev termin naivne umetnosti banaliziral. ${ }^{8}$

Vrstile so se tudi razstave mlajših generacij naivnih slikarjev in kiparjev. Žal pa se je dogajalo, da je bilo njihovo snovanje podrejeno bolj komercialni uspešnosti in ideološko populističnim težnjam kot likovnim kriterijem in razvoju omenjene zvrsti. Izšlo je veliko monografij in razstavnih katalogov, prevedenih v več svetovnih jezikov. Širila se je tudi medijska popularizacija.

Pomembno vlogo pri uveljavitvi in institucionalizaciji naive je imela ustanovitev Galerije primitivne umetnosti v Zagrebu leta 1956 (danes Hrvaški muzej naivne umetnosti). Predani zunanji in notranji strokovni sodelavci galerije so skrbeli za njeno kritično vrednotenje ter tako vzdrževali kakovost. Z njihovo pomočjo so se afirmirali začetniki hlebinske šole ter formirali mlajši slikarji, kot so Matija Skurjeni, Emerik Feješ, Ivan Rabuzin, Petar Smajić, Dragan Gaži, Ivan Večenaj, Mijo Kovačić ter drugi vidnejši predstavniki jugoslovanske naive.

Šestdeseta leta pomenijo zlato dobo za jugoslovansko naivo. Sam Hegedušić se je izrazil, da je zdaj (leta 1969) naivcev in amaterjev kot gob po dežju (Gartnar, 1969, n. p.). Zato tudi ni zaman krožil med ljudmi pomenljiv stavek, da $v$ Hlebinah že za vsakim grmom slika kmet, kot mi je povedala informatorka.

Sedemdeseta leta pomenijo začetek zatona naivne umetnosti tako v Jugoslaviji kot drugod po svetu. $\mathrm{V}$ tem času so vodilni naivni umetniki izgu-

8 Iz pogovora 18.4.2008 v Hrvaškem muzeju naivne umetnosti, Zagreb. 
bili svoj kreativni naboj. Pogubna pa je bila predvsem ekspanzija serijskega ponavljanja in repliciranja hlebinske stilistike in celo plagiatov znanih likovnih del. Zdi se, da je vsa ta produkcija postala podrejena trgu (Gamulin, 1999, 295). Marsikateri slikar, ki se je znal kolikor toliko promovirati, čeprav je bila njegova kakovost vprašljiva, si je s prodajo slik izboljšal gmotni položaj, saj so, po pripovedovanju informatorja, Nemci, Italijani in drugi, predvsem $\mathrm{v}$ času poletne turistične sezone, slike na veliko kupovali. Nekateri posamezniki so celo opustili svoje poklice in se ukvarjali samo še s slikanjem. Prav ti so se pogosto preselili z vasi v mesta. Konec koncev je bila to tudi splošna posledica industrializacije države (Crnković, 2006, 25-26). Razmah zanimanja za naivo, tako s strani ustvarjalcev kot publike, je šel z roko $\mathrm{v}$ roki s splošnim porastom življenjskega standarda in izobraženostjo ljudi. Ti so tako imeli več prostega časa za ljubiteljsko ustvarjanje. Z izobraževanjem pa sta se zvišala splošna zavest ljudi in zanimanje za dejavnosti, ki niso imele neposrednega eksistencialnega pomena.

V zlati dobi šestdesetih let so poleg Koprivnice v Podravini vzniknila še druga središča naive. Jagodina (nekoč Svetozarevo) ${ }^{9} \mathrm{v}$ Srbiji se je poleg zagrebške galerije razvila $\mathrm{v}$ eno redkih strokovnih središč naive $\mathrm{v}$ Jugoslaviji. Nastala so tudi druga likovna središča, ki pa jih je vodil bolj entuziazem kot strokovnost (leta 1955 je bila ustanovljena galerija samoukov v Koprivnici, leta 1960 v Svetozarevu, leta 1963 v Uzdinah, leta 1968 v Hlebinah, leta 1971 v Zlataru in Trebnjem, leta 1972 v Šidu, leta 1975 v Sanskem mostu itd.). V teh mestih so bile organizirane slikarske kolonije, likovni saloni in razstave, nastajati pa so začele tudi likovne zbirke. Razvoj teh središč je imel podlago v kulturni politiki države, ki si je prizadevala za decentralizacijo in popularizacijo kulture in jo želela prenesti iz urbanih središč v manjše kraje.

\section{Tabor likovnih samorastnikov Trebnje}

Tabor likovnih samorastnikov v Trebnjem je bil osnovan leta 1968 in ga moramo razumeti v kontekstu tedanjih družbenih in političnih razmer. Ta-

9 Danes Muzej naivne in mariginalne umetnosti, ki še vedno organizira bienalne likovne kolonije. 
krat so se zveze kulturnih organizacij zavzemale za kulturni policentrizem, kar je v praksi pomenilo, da so bile zunaj večjih urbanih kulturnih središč predvsem poleti organizirane umetniške kolonije. Tako je bil tabor likovnih samorastnikov v Trebnjem na neki način odgovor na vprašanje o oblikah kulturnega življenja $\mathrm{v}$ manjših krajih, kamor je tedaj sodilo tudi Trebnje. To se je ob pomembni prometni povezavi med Ljubljano, Novim mestom in Zagrebom hitro industrijsko razvijalo, s porastom prebivalstva pa posledično tudi urbaniziralo. Poskrbeti je bilo treba tudi za kulturno dogajanje kot eno od oblik preživljanja prostega časa, pa tudi intelektualnega razvoja in socializacije. Kot je povedal Mirko Juteršek, so s prirejanjem likovnih kolonij želeli razširiti ustvarjalno življenje v Trebnjem, kar naj bi povzročilo množičnost in končno demistifikacijo umetnosti, torej zmanjševanje prepada med umetnostjo, ki naj bi spadala v sfero elit, in množicami, oziroma med »producenti« in »konzumenti « umetnosti. To pa je bil tudi glavni cilj številnih drugih likovnih središč in razstavišč v tedanjem času.

Dodaten razlog za nastanek tabora je bil tudi namen predstaviti naivno umetnost v Sloveniji, saj tedaj še ni imela takšnega pomena kot v drugih delih Jugoslavije. V tem času se je za ta likovni pojav uveljavil pojem naivna umetnost, ob katerem pa se je v Sloveniji, zlasti v sedemdesetih letih, razširil tudi izraz »samorastništvo«, ki širše kot naiva povzema ustvarjanje ljudi brez formalne likovne izobrazbe, po drugi strani pa ni brez družbeno angažiranega pridiha, saj zbuja asociacijo na znano novelo Prežihovega Voranca.

Naivna umetnost je bila v slovenskem prostoru prvič predstavljena leta 1962 z razstavo Svet Naivnih z deli iz zbirke Gerharda Ledića v Galeriji Božidar Jakac Kostanjevica na Krki. Leta 1968 se je zvrstilo že več razstav: retrospektivna razstava jugoslovanskega naivnega kiparstva, razstava Ivana Lackovića - Croata v Krškem, Viktor Magyar je razstavljal na Mirni, v Vili Bled pa je svojo zbirko ponovno predstavil Gerhard Ledić (Štepec, 1997, 17).

$\mathrm{V}$ pastoralni in fantazijski motiviki je bilo to likovno snovanje slovenskih »samorastnikov « podobno tistemu, kar je nastajalo pod imenom naiva drugod v Jugoslaviji. Zato se pridružujem mnenju Dušana Štepca, da ne gre razlikovati med slovenskim samorastniškim in jugoslovanskim naivnim likovnim ustvarjanjem. Likovni jezik kvalitetnih slovenskih posameznikov je seveda specifičen, kar velja tudi za druge posamezne kakovostne jugo- 
slovanske ustvarjalce, medtem ko so drugi, slabši avtorji morfološko posnemali »hlebinsko stilistiko«. Želja organizatorjev tabora je bila povezati razkropljene in nepovezane slovenske avtorje ter s tem omogočiti pregled nad to obliko ustvarjanja pri nas. Kmalu, leta 1971, je bila ustanovljena Galerija likovnih samorastnikov v Trebnjem, ${ }^{10} \mathrm{z}$ namenom hranjenja del, ki so jih udeleženci taborov podarili, njihovega predstavljanja ter organiziranja različnih samostojnih in skupinskih razstav priznanih domačih in tujih naivnih umetnikov. Organiziranje tabora ${ }^{11}$ in ustanovitev galerije sta bila $\mathrm{v}$ rokah lokalnih veljakov, ${ }^{12}$ katerim so se priključili uveljavljeni umetnostni zgodovinarji in likovni kritiki. ${ }^{13}$ Sodelovali so tudi z jugoslovanskimi strokovnjaki, galeristi in publicisti. ${ }^{14}$ Vse do leta 2007 so tabore in galerijo večinoma vodili zanesenjaki in prostovoljci z Janezom Gartnarjem na čelu. ${ }^{15}$

Tabor in pozneje galerija sta nastala prav v času največje popularnosti naivne umetnosti oziroma že na začetku konca njenega ustvarjalnega elana.

10 Galerija danes hrani že skoraj 1000 likovnih del, ki jih je prispevalo več kot 250 umetnikov iz 35 držav Evrope, Azije, Afrike, Severne in Latinske Amerike. Med njimi so tudi mojstri, katerih dela so uvrščena v zbirke pomembnih galerij in muzejev po svetu. Kakovostno jedro zbirke tvorijo predvsem dela iz sedemdesetih in prve polovice osemdesetih let, torej obdobja, ko je bila jugoslovanska naiva še v relativnem razmahu, poleg tega pa je tedaj organizacija tabora potekala $\mathrm{v}$ sodelovanju $\mathrm{z}$ najboljšimi jugoslovanskimi poznavalci naivne umetnosti.

11 Tabor se je prvo leto imenoval Tabor slovenskih naivnih umetnikov, naslednje leto pa se je preimenoval v Tabor slovenskih naivnih in ljudskih slikarjev in kiparjev. Leta 1974 se je imenoval Tabor slovenskih likovnih samorastnikov Jugoslavije, že naslednje leto pa Tabor likovnih samorastnikov Jugoslavije (novo ime je samo povzelo dejansko stanje, saj so že na "slovenskih" taborih sodelovali tudi naivni umetniki iz drugih jugoslovanskih republik). Ponovno je bil preimenovan leta 1992, in to v Mednarodni tabor likovnih samorastnikov (novo ime je spet povzelo že obstoječe stanje; širše mednarodno sodelovanje se je namreč razvilo že v sedemdesetih letih). Poimenovanja kažejo tudi na ambicije prirediteljev.

12 Župan Ciril Pevec, predsednik novomeškega sodišča Janez Gartnar in ravnatelj OŠ Trebnje Adolf Grum ter pozneje direktorica Centra za izobraževanje in kulturo Darinka Toplak in tedaj že prepoznavni samouki slikar ter učitelj na Čatežu Viktor Magyar.

13 Nekdanji direktor Moderne galerije Zoran Kržišnik, likovni kritik dr. Mirko Juteršek in nekaj časa tudi nekdanji direktor Mestne galerije Ljubljana Aleksander Bassin ter direktor Loškega muzeja Andrej Pavlovec.

14 Znani hrvaški novinar, publicist in zbiralec naive Gerhard Ledić, publicist in urednik Neboljša Tomašević in zagrebški likovni kritik Vladimir Maleković.

15 Nekateri so mu pri vodenju galerije in taborov očitali avtoritativnost, vendar $\mathrm{v}$ isti sapi priznali, da brez njega te zbirke in likovnih ter kulturnih dogodkov v kraju ne bi bilo. 
Z namenom vzdrževanja likovne in estetske ravni ter razmejevanja med ljubiteljstvom in naivo so leta 1971 organizirali Salon likovnih samorastnikov Jugoslavije. Sledilo jih je še šest, zadnji leta 1984. Nato je salon zaradi finančnih razlogov zamrl. Počasi je začel upadati tudi pomen taborov in galerije. Razlika med salonom in taborom je bila, da so na salon oziroma na izbor za salon avtorji poslali svoje najboljše delo, medtem ko so na taboru v sedmih ali desetih dneh ustvarili likovno delo, katerega kakovost je lahko glede na njihov celotni opus nihala. Kljub temu so dolgoletni udeleženci taborov pritrjevali, da so se pri ustvarjanju vsi zelo potrudili ali celo prinesli s seboj svoje že končano delo. ${ }^{16}$

Kljub popularnosti in dejavnosti tabora ter galerije je bila slovenska naiva $\mathrm{v}$ umetnostnozgodovinskem kontekstu bolj obroben likovni pojav. $\mathrm{Ne}$ moremo pa zanikati umetniške kakovosti začetnikov slovenske naive (oziroma samorastništva): Viktorja Magyarja, Poldeta Miheliča, Antona Plemlja, Antona Repnika, Jožeta Horvata Jakija ter še mlajše generacije - Grete Pečnik, Zlate Volarič, Borisa Lavriča, Janka Dolenca, Sandija Leskovca in Frančiške Petelinšek. Slovenska strokovna javnost je delovanje tabora v glavnem ves čas bolj ali manj zanemarjala, čeprav je s strani stroke pri organizaciji tabora sodeloval tudi Zoran Kržišnik - avtoriteta slovenske galeristike in dolgoletni vodja Ljubljanskega mednarodnega grafičnega bienala.

Dejavnost tabora je bila v slovenskem in jugoslovanskem kulturnem prostoru deležna široke popularizacije, utemeljene v viziji kulturne politike. Ti pomembni dogodki so bili obeleženi predvsem s posebno slovesnimi otvoritvami pod pokroviteljstvom visokih predstavnikov tedanje oblasti.

$\mathrm{V}$ enem od otvoritvenih govorov je Zoran Kržišnik Trebnje označil kot eno izmed evropskih središč naivne umetnosti. Ocene o mednarodni pomembnosti tabora, izrečene ob svečanih dogodkih, so bile včasih tudi zelo pretirane. Čeprav je še leta 1997 Milan Kučan v otvoritvenem nagovoru 30. tabora Trebnje označil kot pomembno evropsko kulturno središče, je bil mnogo bolj stvaren Bogdan Osolnik, ki je v svojem govoru na svečanem zboru leta 1977 o taboru spregovoril takole: »Veseli smo, da postaja naš

16 Včasih so avtorji prinesli replike svojih likovno in komercialno uspešnejših motivov (na primer Ze Cordeiro, Irena Polanec, Jože Horvat Jaki). 
tabor priložnost za taka mednarodna srečanja, čeprav nimamo pretenzij in iluzij, da bi Trebnje lahko postalo nekakšno mednarodno središče samorastništva. Svet je preveč pester in različen, da bi ga na katerem koli področju mogli utesnjevati z uveljavljanjem in vsiljevanjem nekakšnih središč. Čeprav ima jugoslovanska naiva $v$ svetu velik ugled, želimo samo to, da bi se v Trebnjem umetniki iz Jugoslavije srečevali tudi z ustvarjalci iz drugih dežel, zlasti prijateljskih, in da bi prek njih spoznavali življenje in vrednote drugih, da bi tudi to prispevalo $k$ medsebojni ustvarjalni bogatitvi, pa tudi $k$ mednarodnemu zbliževanju.«(1977, n. p.)

O pomenu in namenu tabora in salona ter o pojmovanju in odnosu do naive ter njene komercializacije zgovorno priča besedilo Janeza Gartnarja: "Tabori so srečanja novih ustvarjalcev ter umetnikov $z$ delovnimi ljudmi, ki niso več samo potrošniki kulture in umetnosti, temveč so hkrati in prvenstveno nosilci njene rasti in moči. Dela, ki so nastajala na teh taborih, so bila ocenjena s strani strokovnjakov in likovnih ustvarjalcev - seveda ne po kriteriju, ki ga vsiljujejo nekateri, da lahko umetnost ustvarjajo samo poklicni ustvarjalci, vse drugo pa je samo po sebi manj vredno, ko pa so vendar po nespornih merilih, ki so jih izoblikovala stoletja, med vrhunske umetniške stvaritve uvrščena tudi številna dela samoraslih umetniških stvaritev, še zdaleč pa ne dela vseh profesionalnih ustvarjalcev.

[...] Če ni uspelo onim, ki ponujajo le robo s tekočega traku, ki je še v bli$\check{z}$ nji preteklosti šla dobro $v$ denar, je to pač zato, ker Salon ni razstava pisane dekorativnosti, ki naj spodbuja zanimanje kupcev in zadržuje obiskovalce ob odtekajoči poplavi komercialne naive.

Na razstavi niso dobila mesta dela avtorjev, ki so preveč očitno poskušala pomanjkanje lastne sposobnosti in ustvarjalne moči nadomestiti s spoznanjem drugih ali s ponavljanjem vedno istega, že preveč znanega, niso presegla povprečja, zato tudi ne zbujajo več zanimanja.

Preveliko bi bilo tveganje razstaviti dela, ki že na prvi pogled razkrivajo, da njihovi avtorji ne znajo ali pa nimajo več kaj povedati, pa se tolažijo, da lahko praznino razpno $v$ blesteče okvire naročenih in plačanih kritik ter reklame, ki pa ostaja brez odmeva.« (1979, n. p.) 
Mnenje enega od pobudnikov in organizatorjev teh prireditev je pomenljivo in zanimivo hkrati. Po eni strani priznava problematiko komercializacije naive in njene dekorativnosti, po drugi strani pa je na tabore pogosto vabil ustvarjalce, ki so se zamotali v kopiranje lastnih vzorcev in reproduciranja svojih najbolj znanih likovnih motivov. Nekateri so šli celo tako daleč, da so izdelovali replike ali celo dejansko »industrializirali« svojo »umetnost« s tiskanimi reprodukcijami, jih okrasili z zlatimi lističi ali prahom ter lično okvirili. ${ }^{17}$

O komercialnosti naive so kritično spregovorili tudi sodelujoči likovniki. Članek, ki je bil napisan v času 7. likovnega tabora v Trebnjem leta 1974, nosi udaren naslov Naive ni. Kadar govorijo o naivcih, jih ljudje nevoščljivo žvečijo, ker naj bi služili težke milijone. Avtor je slikarje spraševal, ali publika $\mathrm{z}$ denarjem vpliva na izpovedno moč naivnega slikarstva. Nekateri so bili mnenja, da je denar res prednjačil pred kriteriji kvalitete in da je večina del, ki gredo dobro v denar, zanič. Nekateri so spregovorili o Italijanih, ki s kupi denarja in omamnimi ponudbami begajo labilne slikarje. Ena od sodelujočih slikark, Greta Pečnik, pa je še dodala, da mora slike, ki jih želi obdržati, skriti v omaro, sicer ji vse odnesejo. Grešnega kozla za to komercializacijo vidijo $\mathrm{v}$ lažnih kritikah $\mathrm{v}$ tisku, $\mathrm{v}$ senzacionalističnem napihovanju milijonov, ki naj bi jih naivci služili, in v mehanizaciji zasebnih preprodajalcev. ${ }^{18}$

Na taboru so sodelovali jugoslovanski in slovenski, ${ }^{19}$ pa tudi tuji priznani in manj znani naivni ustvarjalci, ki so imeli svoj specifičen likovni izraz in motive. Prišli so tudi tisti samouki, ki ustvarjajo v maniri »hlebinskega sloga « kot prepoznavni naivni formi, ali pa so v vsebini izbirali ruralne

17 Toliko bolj ironično je, da so bili organizatorji tabora, ki so kritizirali komercializacijo, vanjo posreno ali neposredno vključeni. Nekateri so menda tako finančno podpirali mednarodne umetniške (elitne) dogodke. Po pričevanju informatorjev tabori niso bili zgolj druženje in izmenjavanje mnenj med ustvarjalci in širšo strokovno ter laično publiko, bili so tudi neke vrste sejmi likovnih del. Tudi danes ustvarjalci prinesejo več svojih del za prodajo. Kljub temu je treba poudariti, da prodaja na splošno ni bila glavni razlog za sodelovanje na taboru.

18 Članek hrani hemeroteka arhiva Galerije likovnih samorastnikov. Publikacija, avtor, letnica in paginacija so neznani.

19 V nasprotju z nekaterimi najpomembnejšimi hrvaškimi naivci začetniki slovenske naive večinoma niso bili kmetje: Viktor Magyar je bil učitelj, prav tako Polde Mihelič, Anton Plemelj upokojeni major, Anton Repnik iz Mute na Koroškem je bil delavec v železarni, Greta Pečnik pa gospodinja iz Pirana (Komelj, 2006, 126). 
etnografske motive. Informatorka, ki se je udeležila številnih taborov, je na vprašanje, zakaj ustvarja prav v formalnih okvirih naive, odgovorila: »To je bilo takrat zelo popularno, vsi so slikali tako. "Drugi informator je dejal, da se je naivnemu »slogu « in vsebini prilagodil, ko je bil povabljen na tabor. Sledil je sugestijam Janeza Gartnarja in Zorana Kržišnika ter opazoval druga dela. Začel je posnemati določene vzorce naive in ruralno motiviko. $\mathrm{Na}$ svoje likovno delo gleda zelo pragmatično; pove, kateri motivi gredo dobro $\mathrm{v}$ promet in kaj ljudje pri njem naročajo. Likovnik mi je s ponosom povedal, da se je njegov družbeni in finančni položaj izboljšal.

$\mathrm{Na}$ taborih so prisostvovali tudi avtorji iz Južne Amerike, Afrike, skoraj vseh evropskih držav, Turčije in celo iz Japonske. Zelo težko je trditi, da so bili vsi naivni ustvarjalci, tako $\mathrm{v}$ kontekstu definicije naive kot $\mathrm{v}$ formalnih in vsebinskih okvirih. Nekateri so bili celo formalno šolani slikarji. Vsa ta pestrost pokaže, da sta kritičnost in elan tabora z leti upadla. Pokazal se je tudi problem, da širša javnost in ustvarjalci ne poznajo ločnice med naivno umetnostjo in amaterizmom, na kar je Depolo opozoril že v šestdesetih letih. Samozavest številnih t. i. naivnih slikarjev, ki so pogosto mejili na amaterizem, je tako zrasla, da so začeli, z željo po vse večjem uveljavljanju in razstavljanju svojih del, pritiskati na javne zavode, muzeje in galerije. Po pričevanju starejših muzealcev so tako nastajali resni konflikti med strokovnimi delavci in nekritičnimi likovniki ter javnostjo.

Tedanja socialistična politika, ki je vzela naivo pod svoje okrilje, se tudi ni pretirano ukvarjala $\mathrm{z}$ razlikovanjem med pravo naivo in amaterizmom. Idejno izhodišče za podporo likovnim kolonijam in likovnemu ustvarjanju sploh je jasno opredelil Program Zveze komunistov Jugoslavije, sprejet na VII. kongresu ZKJ v Ljubljani. V njem je bilo začrtano prizadevanje, da naj bi umetnost in kultura na splošno zares postala last ljudstva in da naj bi kulturno ustvarjanje dobilo masovno podlago, pri čemer je posebej poudarjeno spodbujanje kulturno-umetniške dejavnosti in iniciative najširših ljudskih množic (Manifest b. n. 1., 290; po Komelj, 2007, 129). Dejavnost trebanjskega tabora je bila razumljena kot eden zglednih primerov takšnega spodbujanja in ni naključje, da je prvo veliko zlato plaketo tabora leta 1978 prejel Josip Broz Tito (Razstavni katalog, 1982, n. p.). 
V skladu s takšno percepcijo so bili zastavljeni tudi poudarki v govorih političnih funkcionarjev, ki so se udeleževali slovesnih otvoritev trebanjskih prireditev. Kot tipičen primer naj navedem odlomek iz govora Staneta Dolanca leta 1971, v katerem je tabor razumel kot pomemben dejavnik v samoupravni preobrazbi kulture $\mathrm{v}$ smislu integracije kulture in umetnosti s celoto združenega dela: »Naša samoupravna socialistična družba bije danes zapleten boj, katerega neposredni cilj in osnovna misel je še bolj drzno in odločno razvijati začete procese, ki peljejo $k$ splošni osvoboditvi dela, delavskega razreda in človeka. Kultura in umetnost sta močni orožji tega človekovega boja, ki celo predpostavlja, da se kultura in umetnost razvijata kot integralni del revolucionarne preobrazbe družbe in da se sami osvobajata še močnejših pritiskov cehovske in etatistične zavesti, da bi postali lastna sila delavskega razreda in delovnega človeka." Govornik v nadaljevanju poudarja, da »umetnost in kultura zadovoljujeta naraščajoče kulturne potrebe našega delovnega človeka samoupravljavca ter da razvijata njegovo kulturno delo in življenje. »Demokratizacija kulture in umetnosti, če smo že sprejeli ta pojem, pa seveda pomeni tudi to, da še bolj širimo množično kulturno-umetniško ustvarjalnost, samoizražanje delavcev, mladine, občanov, skratka, vseh članov naše družbe ..." (n. p.) To vsebino je nadgradil leta 1974 ob otvoritvi 3. salona jugoslovanske naive: "Takšna idejno-politična naravnanost nam je omogočila, da odločneje razkrinkujemo buržoazno in tehnobirokratsko vsebino tradicionalističnih pojmovanj kulture. Ta pojmovanja postavljajo kulturne dejavnosti $v$ podrejen odnos neposredni ekonomski rentabilnosti ali pa jo omejujejo zgolj na sektor splošne porabe.« (n. p.)

Vsebinska domačijskost, ki prevladuje v likovnih delih, je bila vzneseno opisana in interpretirana v uvodnikih razstavnih katalogov. Predindustrijska krajina, ki izginja ali pa je že dolgo ni več, je bila opisana in interpretirana kot domačijsko okolje, skoraj takšno, kakršnega smo vajeni pri vesnanih (Pavlovec, 1973, n. p.).

Kržišnik je zapisal: »Vrednost naive smo do nedavnega videli v obujanju začaranega sveta otroštva, $v$ idealizirani podobi preteklosti, ki prinaša $v$ mrzličnost in razdrobljenost sodobnega sveta sladke sanje o dobi, ko je bilo življenje še smiselno in nezahtevno in se je gibalo $v$ zloženem ritmu letnih časov, ko je trdemu delavniku sledil veseli praznik z obilico slikovitih običajev in pisanih noš. [...] Ni razčustvenost tisto, kar je osnovna karakteristika sa- 
morastnikov in njihova kvaliteta: nasprotno, gre za kleno, neposredno izražanje bistvenih spoznanj, za vizualni zapis posameznikov in ponekod celo vasi, ki se znajo bolje in lažje izpovedati v podobi kot v napisani besedi. Njihovo sporočilo je učinkovito in zgovorno in direktno vstopa $v$ gledalčevo zavest." (Kržišnik, 1992, 2) »[...] Vračanje h koreninam. In eno izmed takšnih vračanj je nedvomno tako zelo povečano zanimanje za dela neučenih samoraslih umetnikov, tistih, ki ustvarjajo brez sistematičnega šolanja, tako rekoč »iz svojega«, iz vrela prvinske človeške ustvarjalnosti.« (1971, n. p.) Podobno romantičen pogled je vladal še deset let pozneje. »[...] ustvarjanje slovenskih naivnih likovnih umetnikov, ponekod izvirajoče tudi iz izumirajoče narodne umetnosti, pa vendarle močno s svojo izvirno prostodušnostjo in predvsem $z$ zajemanjem temnih in svetlih strani neposrednega življenja ..." (Gošnik, 1982, n. p.)

Množična kulturno-umetniška ustvarjalnost je bila povezana tudi $\mathrm{z}$ industrijo, kakor priča oglas v razstavnem katalogu: »Ta razstava je podoba zveze kulture in združenega dela. Prehrambena industrija Podravka že vrsto let aktivno sodeluje pri oblikovanju kulturne politike.«(1982, n. p.)

Presenetljivo je, kako sta lahko v takšnem razumevanju sovpadali radikalna revolucionarna retorika in domačijska samozadostnost. Kako lahkotno so se tu pomešale tendence po spreminjanju sveta in nostalgična idealizacija obstoječega oziroma izginjajočega, idejni avantgardizem in folklorizem (Komelj, 2007, 129).

Tabor in galerija sta prehodila pestro pot. Doživela sta kar nekaj svetlih trenutkov, od razstav izbora iz zbirke v tujini do proslavnih spektaklov, na katerih so bili govorniki pomembni visoki politiki in kulturniki. Občinsko družabno in kulturno življenje se je nekaj časa vrtelo predvsem okoli galerije in taborov. Zaradi razpada države in sistema, spremembe kulturne politike ter posledično tudi manjše finančne podpore in ker se je konec koncev historična naiva končala in tako posledično ni ponudila nove ustvarjalne moči ter novih strokovnih smernic, se je konec devetdesetih let dejavnost tabora in galerije znašla $\mathrm{v}$ krizi. Zdelo se je, da bo aktivnost popolnoma zastala, zbirki pa je grozilo, da jo bodo razdali. Kljub vsem tegobam je tabor letos doživel že svojo 42. ponovitev. Vendar se je znašel v slepi ulici. Z namenom iskati rešitve in odgovore na programska vprašanja galerije je bila 
februarja 2008 organizirana okrogla miza, ki je pokazala dvoje. Prvič, tudi v Sloveniji je stroka potrdila, da je historične naive konec in se ne razvija naprej, kakor menijo nekateri starejši umetnostni zgodovinarji. Kar pod imenom naiva nastaja na taboru zadnjih dvajset let, je že davno preseglo okvire pojma in pojava naive. Gre bolj za nostalgično ponavljanje všečnih vzorcev, torej preverjenih in široko sprejetih motivov, vsebin in form, ki pa nimajo več tako širokega občinstva in kupcev kot nekoč. Na drugi strani se domača javnost in ustvarjalci zelo težko sprijaznijo s tem dejstvom, saj se počutijo, kot da bi jim hoteli vzeti pravico in smisel ustvarjanja ter organiziranja likovnih dogodkov. Treba je pripomniti, da je večina ustvarjalcev upokojencev, ki so se vrvežu naivnega ustvarjanja pridružili v svojih mlajših kreativnih letih. Enako je z obiskovalci galerije in taborov, ki se navdušujejo nad deli. Povezuje jih nostalgični kolektivni spomin na "zlate čase« šestdesetih, sedemdesetih in delno tudi osemdesetih let Titove Jugoslavije, ki se zrcali v likovnih delih zadnjega obdobja naive, in sicer v žanrsko domačijskih prizorih, polnih idile in optimizma, romantičnih krajinah in tihožitjih ter partizansko-revolucionarnih podobah.

Vendar je zadnji tabor pokazal, da še vedno nastajajo kakovostna dela posameznih samouških slikarjev in da bo vedno obstajalo povpraševanje po figuraliki in slikah $\mathrm{z}$ lahkotnejšo, pogosto pastoralno pripovedno vsebino.

\section{Popularna kultura}

Tako kot definiranje naivne umetnosti je tudi definiranje popularne kulture težavno, saj gre za dokaj izmuzljiv pojem, ki se ga pogosto enači $s$ terminom množična kultura. Peter Burke ugotavlja, da sta obe besedi, "popularna « in »kultura«, dvoumni. Termin "popularna« izvira iz latinske besede "populus«, torej ljudstvo. Toda katero ljudstvo, se sprašuje Burke. Prav tako termin »kultura" pomeni več stvari, vendar jo avtor definira kot porazdeljenje ali (vzajemno) deljenje vedenja (shared attitudes) pomenov in vrednot, izraženih v izdelkih in storitvah. Pred nekaj stoletji je še bilo mogoče ločiti med visoko in ljudsko oziroma popularno kulturo, danes pa 
se ne izključujeta več (Briggs, Burke, 1985, 39-41), temveč se vzajemno prepletata. Ko govorimo o popularni kulturi ter njenih nasprotjih in sopomenkah, jo pogosto interpretiramo in razlagamo skozi prizmo umetnosti.

Rajko Muršič z rabo termina "popularna kultura« označuje kulturo, ki ni elitna in ima bistveno širši obseg od termina »množična kultura«. To razume kot sodobno kulturo, ki zaznamuje možnost neskončne reprodukcije (2000, 22-23). Proizvodi "množične kulture« so v veliki meri posredovani skozi množične medije, ta kultura pa se ohranja, če povzamemo po Walterju Benjaminu, s produkcijo reprodukcije kulturnih dobrin (1981, 66-92), medtem ko naj bi bila popularna kultura tista, ki v vsakem primeru najizraziteje zaznamuje življenje večine ljudi (Muršič, 2000, 63). Vendar je to pojmovanje problematično, saj vsaka kulturna dobrina, posredovana skozi množične medije, ni nujno "množična«, pravi Muršič, medtem ko se v popularni kulturi skriva beseda »populus«, torej ljudstvo, kot je omenil že Burke. V slovenski etnološki literaturi je bila množična kultura tista kultura, ki je med najnižjimi sloji v obdobju industrializacije zamenjala ljudsko (kmečko) kulturo. Ta opredelitev le delno pokrije širok spekter sodobne popularne kulture, ki nikakor ni več vezana na posamezne družbene sloje. In prav v tem je njena moč (Muršič, 2000, 63). Popularna kultura nima enotnega vira in postaja vse bolj dominantna kultura (Muršič, 2000, 64).

Popularno kulturo nemalokrat opredeljujemo kot nasprotje visoke kulture. V osnovi naj bi se popularna in visoka kultura ločili v kontekstu estetskega vrednotenja. Vendar se pojem visoka kultura pojavi šele vzporedno s pojmom ljudska kultura, in sicer v času, ko so se romantiki zoperstavili trivializaciji umetnosti. Zahtevali so popolno avtonomijo ustvarjanja, ne oziraje se na splošen okus in zahteve trga. Ker so se vedno bolj umikali iz javne sfere, je bila tudi njihova umetnost razumljiva le določeni (izobraženi) eliti. Z namenom vzpostavitve nadzora nad morda že pregovorno uporno umetnostjo je meščanstvo visoko kulturo institucionaliziralo, jo postavilo nazaj v javno sfero in tako vzpostavilo sistem nadzora (Debeljak, 1999). S tem se je vzpostavilo tudi razmerje med družbenim razredom in kulturo. Termin popularna kultura je iznajdba intelektualcev razsvetljenstva in že omenjene romantike, pravi John Story in nadaljuje, da popularno kulturo razume kot način kategoriziranja in opredeljevanja kulturne prakse »navadnih «ljudi (2003, xi-xii). Njen koncept je izšel v poznem 18. stoletju, ko se je s tem terminom opre- 
deljevala kvazi mistična ruralna ljudska kultura (Story, 2003, 1). »Odkritje« ljudske kulture pa je bilo sestavni del razvoja evropskih nacionalizmov (Smith, 1991, 2005). Popularna kultura je nastala kot posledica industrializacije ter urbanizacije, torej z zmagoslavnim pohodom kapitalizma. Delno je bila osnovana $\mathrm{z}$ nastankom delavskega razreda, delno pa kot odgovor buržoazije, ki je z visoko kulturo poudarjala svojo superiornost (Story, 2003).

Marksistično pojmovanje množične kulture oziroma tistih produktov in procesov, ki jo proizvajajo, sta v bran elitne kulture Theodor Adorno in Max Horkheimer poimenovala »kulturna industrija«. Kulturne komoditete, ki so produkti kulturne industrije, so zaznamovane s homogenostjo (množični mediji). Prav ta homogenost množice nadzira in z njimi manipulira. Tako trdita, da je kulturna industrija depolitizirala delavski razred, omejila njegov horizont v političnih in ekonomskih ciljih, ki se lahko realizirajo znotraj opresivnega in izkoriščevalskega okvira kapitalistične družbe. Množična kultura je namreč podana od zgoraj za nadzor in manipulacijo množic, ki so le še pasivni uporabniki $z$ omejeno možnostjo izbire (2000, 3-19).

Walter Benjamin se je skozi obravnavo umetniškega dela v času tehnične reprodukcije skušal, po mojem mnenju, dotakniti prepleta visoke in popularne kulture. Čeprav je dajal prednost klasični umetnosti, je kljub temu uvidel, da nove umetniške zvrsti (na primer fotografija) ne morejo obstajati brez reprodukcijskih sredstev in nosilcev oziroma matrice (film). V reprodukciji klasičnega umetniškega dela se njegova enkratnost, pristnost in neponovljivost zamenjuje z množičnim, analognim, ponovljivim $(1981,71)$. Tehnično reproduciranje spreminja odnos množic do umetnosti - kritično vedenje in zaznavanje umetnosti se zmanjšuje. Vzpostavi se hedonistično razmerje do nosilcev umetnosti brez pretiranega intelektualnega vložka $(1981,84)$. Poleg tega reprodukcijske tehnike ločijo reproducirano od tradicije. V kontekstu slednje se je funkcija umetniškega dela nekoč utemeljila $\mathrm{v}$ ritualu. $\mathrm{Z}$ izgubo pristnosti $\mathrm{v}$ reprodukciji pa se je spremenila funkcija umetnosti, ki zdaj izhaja iz prakse - iz politike (1981, 70-73).

Zgodovinska avantgarda se je zavzemala za brisanje meje med visoko in popularno kulturo: visoko umetnost je hotela približati čim širšim množicam. Vendar Huyssen ugotavlja, da je avantgarda, ki je bila povezana z radikalno politiko in je delovala kot ostra kritika uradnega kanona meščanske 
kulture in umetnosti, po drugi svetovni vojni postala konformistična. To se manifestira $\mathrm{v}$ njeni depolitizaciji in institucionalizaciji kot administrativna kultura in $v$ akademski interpretaciji, ki je kanonizirala historično avantgardo, modernizem in postmodernizem ter tako $v$ industrializirani civilizaciji metodološko služila vitalni dialektiki med avantgardo in množično kulturo $(1989,4)$.

Avantgarda je konec 19. in začetek 20. stoletja skušala skozi umetniško ali likovno govorico sporočati napredne ali radikalne ideje ter vsebine. Pri tem se je poslužila reprodukcijskih medijev (plakat, fotografija, film, tisk), torej predvsem tehnologije, ki jo je častila. Vendar pa se je vse to že v totalitarnih režimih prve polovice 20. stoletja obrnilo zoper njo in jo tudi uničilo. Tako je postala orodje legitimacije režimov. ${ }^{20}$ Oblike, ki jih je zasnovala avantgarda pri poskusu spreminjanja vsakdanjega življenja in družbenopolitične stvarnosti, so prešle v popularno kulturo. Paradoksalno je, da je prav avantgarda, ki se je borila proti meščanskemu koncipiranju umetnosti in lepote, $s$ časom postala domena tega meščanstva.

Popularne kulture si ne moremo zamisliti brez uporabe različnih tehnologij medijev in tehnologije transporta. Tako sloni na tehnologiji masovne produkcije in reprodukcije, kar homogenizira različnosti. Prav tako pa si avantgarde ne moremo zamisliti, kot je bilo že omenjeno, brez tehnologije, saj je prav ta odigrala ključno vlogo; z njeno pomočjo je namreč avantgarda skušala preseči umetniško in življenjsko dihotomijo (Huyssen, 1989, 9).

Ironično je, pravi Huyssen, da je tehnologija pomagala iniciirati avantgardno umetniško delo in njegov radikalni prelom s tradicijo. Vendar je bila prav ta avantgarda oropana svojega nujnega življenjskega prostora $v$ vsakdanjem življenju. Zato pa je bila kulturna industrija in ne avantgarda tista, ki ji je v 20. stoletju uspelo transformirati vsakdanje življenje $(1989,15)$.

Sicer pa je že Greenberg primerjal avantgardo in kič, ki ga lahko razumemo kot reproduciranje všečnih vizualnih proizvodov brez visokih

20 V Sovjetski zvezi je bil namen umetnosti vplesti se v vsakdanje življenje skozi lepoto in uporabnost (umetnost množičnih demonstracij, festivalov ...). Ruska avantgarda je skušala ustvariti socialistično množično kulturo. Legitimna pozicija kulturne avantgarde, ki je nekoč utopično upala na emancipacijo popularne kulture pod socializmom, je bila povožena z vzponom popularne kulture, ki jo podpirajo institucije in industrija. 
estetskih vrednosti (estetske funkcije kiču po mojem mnenju ne moremo popolnoma vzeti). Po njegovo se je ta radikalna struja skušala otepati okov buržoaznega primeža, vendar ni mogla delovati zunaj ekonomskega sistema, saj je za svojo uveljavitev in preživetje potrebovala denar in tehnologijo prav te buržoazije. Kič je po njegovem mnenju proizvod industrijske revolucije, ki je urbanizirala množice na Zahodu ter vzpostavila tisto, čemur pravimo univerzalna pismenost. Mar ni bila to želja avantgarde?

Greenberg pogumno zastavi: »Visoka kultura je ena najbolj umetnih človeških stvaritev in naš kmet ne čuti v sebi nobene naravne nuje, ki bi ga vsem težavam navkljub gnala $k$ Picassu. Končalo se bo tako, da se bo kmet, kadar si bo zaželel gledati slike, vrnil h kiču, saj v tem lahko uživa brez truda. Država je pri tem nemočna in bo tako še naprej, dokler problemi produkcije ne bodo rešeni na socialističen način. Enako velja za kapitalistične države, kjer je prav zaradi tega vsakršno govorjenje o umetnosti za množice zgolj prazna demagogija.

[...] Spodbujanje kiča je samo še en poceni način, na katerega se totalitarni režimi prilizujejo svojim državljanom. Ker ti režimi - tudi če bi hoteli-ne bi mogli dvigniti kulturnega nivoja množic drugače kot tako, da bi postali del mednarodnega socializma, se množicam dobrikajo tako, da vso kulturo znižujejo na njihov nivo.

Kič omogoča diktatorju neposreden stik $z$ dušo ljudstva.« (Greenberg, 1999, 142-149)

Popularna kultura je invencija intelektualcev in opredeljuje kulturne prakse, vrednote in okus množic. Odvisna je od tehnoloških produkcijskih in reprodukcijskih sredstev ter konzumiranja, ki je v bistvu tudi oblika reprodukcije produkcijskih sredstev. Ta so skoraj vedno v rokah vzvodov moči, kot so država, premožni posamezniki ali koorporacije, in državnih ali mednarodnih institucij, ki z lastnino ali nadzorom nad sredstvi množice usmerjajo in nadzorujejo tako, da jim skozi masovne medije, kulturne spektakle in izobraževanje (kar Althusser poimenuje ideološki aparat države) posredujejo vrednostni sistem, družbena razmerja in odnose - na kratko, da ljudi socializirajo po želenem kalupu. Občasno pa vznikne kulturno gibanje, ki se zoperstavi razmerjem moči. Okus, vrednote in sprejemanje različnih oblik kulture tako niso odvisni le od posameznikove volje ali želje, temveč so pogosto ali predvsem odvisni od vzvodov moči, ki določajo, kaj 
je »in « in kaj »out «. Tako prodirajo v vse javne in zasebne pore vsakdanjega življenja. Četudi se razmerja moči (revolucionarno) obrnejo, se avantgardne ali subkulturne oblike čez čas stopijo s popularno kulturo.

\section{Med naivno umetnostjo, popularno kulturo in pastmi ideologije}

Skozi prizmo Tabora likovnih samorastnikov Trebnje sem v članku skušala prikazati, kako je likovni pojav jugoslovanske naivne umetnosti prerasel $\mathrm{v}$ družbeni in kulturni fenomen, in to prav s podporo in usmeritvijo kulturne politike socialistične države, ki je tudi tako skušala egalizirati in demokratizirati družbo s preseganjem razlik med elitno in popularno kulturo. Tako je prizadevanje po družbeni uveljavitvi »delavnega človeka« prešlo tudi na področje umetnosti. V samoupravnem državnem modelu, ki se je načelno odpovedal administrativnemu interveniranju v umetnostno sfero, je bila načrtno izdelana strategija preseganja nasprotja med proizvajalci in porabniki na področju kulture. Protežiranje naivne umetnosti je mogoče razumeti kot zgled tega preseganja. Za primer navajam Matijo Murka, ki je o trebanjskem taboru zapisal: »Naj postane tabor eno od delovišč, na katerih se podirajo včasih na videz neuničljive pregrade med umetniško ustvarjalnostjo poklicnih umetnikov in samoukov.« $(1970,2)$ Decentralizacija kulture, kot so temu rekli, je potekala $\mathrm{z}$ ustanavljanjem različnih kulturnih žarišč in prirejanjem kulturnih dogodkov v podeželskih krajih. Tako je oblast prek ideološkega aparata države (kulturne institucije in spektakli, mediji, tudi šola), ki deluje $\mathrm{z}$ ideologijo (za razliko od državnega aparata, ki deluje $\mathrm{s}$ silo) (Althusser, 1980, 52), ljudi skušala socializirati v duhu ideje družbenega samoupravljanja in socializma (Muršič, 2000, 60-62, 65).

$\mathrm{Z}$ razumevanjem razmerja med ideologijo in umetnostjo lahko lažje razložimo in razumemo, zakaj je postala naivna umetnost kot medij za posredovanje ideologije tako prikladna. Po Marxu je ideologija sistem idej in predstav, ki vladajo nad duhom posameznika ali družbene skupnosti (Althusser, 1980, 62). Althusser pa razvije tezo, da si ljudje v ideologiji ne predstavljajo svojega realnega sveta, $v$ ideologiji je predvsem predstavljeno razmerje do ek- 
sistenčnih pogojev, ki je v središču vsake ideološke, torej imaginarne predstave realnega sveta $(1980,67)$. Posebnost umetnosti vidi v tem, da nam »daje videti«, »daje zaznavati«, »daje čutiti« nekaj, kar aludira na realnost. Vse našteto (videnje, čutenje in zaznavanje), kar nam umetnost daje, je ideologija (Althusser, 1980, 324), torej tista imaginarna predstava realnosti. Omenjena spontanost, ki je prisotna v opisovanju naivne kreativnosti, po Althusserju izraža ideološko govorico, saj pravi: »Prav dobro vem, da se tako umetnik kot ljubitelj umetnosti spontano izražata $v$ terminih »kreacije itd. To je spontana govorica, vendar pa že od Marxa in Lenina vemo, da je sleherna "spontana" govorica ideološka govorica, da prinaša neko ideologijo ...« $(1980,326)$

Erjavec meni, da je obdobje modernistične umetnosti (v katero spada historična naiva) hkrati obdobje največje in najintenzivnejše ideologizacije moderne družbe $(1988,138)$. Umetnost ali umetniški diskurz je praviloma sicer lahko izraz določene ideologije in $v$ tem pogledu njen sestavni del, vendar hkrati vsebuje določen presežek, ki razkriva in s tem spodbuja prvotni hoteni ali nehoteni ideološki zastavek. Vendar pa umetnosti, predvsem pa njenih funkcij ali učinkov, ne moremo omejiti na ideologijo, marveč je ta lahko le določen aspekt umetniškega dela. Zato je umetnost znotraj družbenega imaginarija tisti del, ki ima pretežno neideološke učinke (Erjavec, 1988, 138). Kar je predstavljeno z estetskim učinkom, ne more biti enako ideologiji. Kakor ugotavlja Erjavec, je populistični odnos do umetnosti najmočneje viden $\mathrm{v}$ tistih okoljih, ki so manj razvita in jim vladajo totalitarne doktrine $(1988,136)$. Titova Jugoslavija pri tem ni bila izjema. Če predpostavimo, da deluje ideologija bolje in učinkoviteje v sferi popularne kulture, je lahko prav estetsko vrednotenje tisto, ki ji zapre vrata v visoko kulturo. Seveda pa je treba poudariti, da stvari niso tako enoznačne in enosmerne.

Razvoj naivne umetnosti in njen pojav na Hrvaškem je bil vključen v širši pojav historičnih avantgard in je tako del moderne umetnosti. »Odkritje« in predstavitev nadarjenih podravskih kmetov je Krsto Hegedušić vključil v tok hrvaške avantgarde, ${ }^{21}$ ki je tako kot druge avantgarde skuša-

21 V času socialistične Jugoslavije skupina Zemlja ni bila deležna znanstvene obravnave (Depolo, 2001a, 9-54). Razlog je iskati v narodnem (nacionalističnem) podtonu, ki ga je izražala. To pa se ni skladalo z idejo bratstva in enotnosti, torej poskusa zatrtja vseh vrst nacionalizmov, ki jim je na koncu kljub temu uspelo razbiti državo. 
la skozi umetnost posredovati svoje politične in družbene ideje po spremembah in osvoboditvi izpod togih meščanskih okov ter hkrati umetnost približati najširšim množicam in jih tako tudi spodbuditi, da bi se v njej sami udejstvovali. Zanimivo je, da je vsebina hlebinske šole in slikanje na steklo, ki je značilno zanjo in posledično tudi za jugoslovansko naivo, plod mentorstva Krsta Hegedušića. Tako se razbije romantični mit o izoliranem, spontanem, umetniškem talentu jugoslovanskega kmeta ali proletarca.

Po vojni je mednarodna slava nespornega umetniškega talenta Ivana Generalića in drugih vodilnih naivnih umetnikov mlajših generacij (na primer Ivana Rabuzina, ki ga na Japonskem zelo cenijo) pripomogla k uveljavitvi jugoslovanske naive $\mathrm{v}$ svetu ter doma - ne le k uveljavitvi, temveč tudi popularizaciji in komercializaciji. Vendar menim, da je pri tem imela enako pomembno, če ne še pomembnejšo vlogo jugoslovanska kulturna politika, ki je po eni strani imela izvrstno promocijsko gradivo za tujino, po drugi pa praktično ideološko orodje za legitimizacijo režima. Čeprav se zdi, da je socialistična politika gradila na podobnih idejnih konceptih kot historična avantgarda, se vendar pokaže nasprotno in se potrdi Huyssenova teza. Forme in načini komunikacije naivne umetnosti z občinstvom so postale del popularne kulture in ta, ne umetnost, je spreminjala vsakdanje življenje in družbeno stvarnost. Tvorjenje odnosov in razmerij med likovno produkcijo in kulturnimi ter družabnimi dogodki, lokalnimi kulturnimi institucijami ter zanimanje medijev se je vzpostavilo v kontekstu ideološkega aparata države, ki spada v privatno sfero (Althusser, 1980, 52). Uspeh države je bil zagotovljen, čeprav oblast verjetno ni predvidevala skorajšnje divje komercializacije in s tem posredno tudi družbenega razslojevanja. ${ }^{22} \mathrm{O}$ bogatenju »umetnikov« so se kritično razpisali tudi mediji ter tako pokazali na razkol med ideologijo in družbeno stvarnostjo. Ustvarjalci in organizatorji likovnih dogodkov so izkoristili ugodno politično klimo, ki jim je zagotavljala obstanek in razvoj ter gmotno stabilnost. Prazna revolucionarna retorika o naivni umetnosti je bila zgolj kulisa, tako kot »spoznanja» nekaterih ljudi iz

22 Po pričevanju informatorjev iz vrst slikarjev in kiparjev so oni in tudi drugi likovniki zelo izboljšali gmotni položaj tako sebi kot svojim potomcem. Nemalo jih je iz revnih vasi prišlo v prestolnico (na primer Zagreb), kjer so si zgradili hišo v elitnem delu mesta. 
stroke. To ideološko protislovje je vidno tudi v govorih in besedilih vidnih političnih in kulturnih osebnosti.

V političnem govoru Staneta Dolanca in besedilu Zorana Kržišnika o vrednotenju naive iz leta 1971 se prepletata revolucionarna progresivnost in meščanska konservativnost. Dolanc vizionarsko govori o kulturi in umetnosti kot o vidnem integralnem delu revolucionarne preobrazbe družbe, ki se osvobaja pritiskov buržoazne zavesti, da bi postali last delavskega razreda. Medtem Kržišnik $v$ začaranem svetu idealizirane preteklosti vidi vračanje $h$ koreninam.

Vračanje k izvornosti je pogosto jedro ideologije nacionalizmov (Smith, 1991, 91). Kako naj si torej razlagamo romantične ruralne vsebine, ki so prevladovale $\mathrm{v}$ jugoslovanskem naivnem slikarstvu in ki so bile tako všečne najširšim množicam? Večnacionalna država se je ves čas obstoja borila proti kakršnim koli nacionalizmom, vendar pa se je očitno paradoksalno v afirmaciji politične ideologije bratstva in enotnosti posluževala metod nacionalizma. Ta namreč poudarja kulturno zasnovo in reprezentacijo, saj zahteva potopitev v kulturo naroda: odkrivanje (Smith, 2005, 16) ali invencija določenih kulturnih oblik. To se kaže v obnavljanju edinstvenih kulturnih identitet - vračanje $\mathrm{k}$ lastnim avtentičnim koreninam oziroma odkrivanje in ponovno spoznavanje »ljudske« kulture. Vse to pa se mora manifestirati v javni obliki, v politizirani množični kulturi (Smith, 2005, 50-51). Poleg tega je za nacionalizme vzhodne Evrope značilno, da so bili njihovi protagonisti intelektualci, ki so izvirnost svojega naroda iskali v kmečki kulturi. Le spomnimo se Hegedušića, ki je iskal izvorno hrvaško umetnost in jo »našel « v Hlebinah. Vendar pa ga v tem pogledu težko označimo za nacionalista.

Socialistična država je skušala oblikovati narod Jugoslovanov, ki bi temeljil na solidarni ideji bratstva in enotnosti. Skupne korenine je bilo najlaže iskati v posplošeni kmečki folklori, saj je Jugoslavija do druge svetovne vojne in še desetletja po njej kljub poznejši pospešeni industrializaciji veljala za pretežno agrarno državo. V iskanju skupne kulture jugoslovanskega naroda je KPJ našla skupne imenovalce za kolektivno reprezentacijo večnacionalne države prav v pastoralni idili in dekorativnosti. Naivna umetnost je bila kot naročena za njeno vizualno predstavljanje. Poleg tega pa je v mo- 
tiviki naive ne ravno redko možno najti komunistične simbole ter legende o junakih NOB in industrijskem napredku.

V besedilu sem skušala prikazati tudi zmotnost romantičnega mita o spontanem samouštvu naivnih umetnikov ter njihovi popolni izoliranosti in osamljenosti od sodobnih umetniških, intelektualnih in družbenih tokov. Dejstvo je, da je bila naiva tako kot druge likovne prakse, pogojena s časom in prostorom, torej da ima svoj začetek, vrhunec in konec. Tako je popolnoma zgrešeno mnenje, da je naiva brez razvoja oziroma zunaj razvoja sodobne umetnosti. Talentirani in kreativni naivni umetniki se niso razvili kar sami od sebe brez kakršne koli pomoči. Razvidno je, da brez zainteresiranih posameznikov (intelektualcev), ${ }^{23} \mathrm{ki}$ so pomagali, učili in spodbujali nadarjene posameznike ter o njih pisali, naive, kot jo poznamo, sploh ne bi bilo.

Priznati je treba, da so nekateri umetniki (eni bolj, drugi manj) podpirali ali celo širili romantično podobo in mit o svojem ustvarjanju in izvoru, saj se jim je zdela to najboljša predpostavka za njihovo umetniško afirmacijo (Crnković, 2002a, 221), pa tudi komercialno uspešnost. Temu so pridali svoj lonček še galeristi in trgovci z umetninami, ki so ta mit tudi sami reproducirali v uspešno reklamo, nenazadnje pa je šel na roko tudi vladajoči ideologiji.

Za namene legitimacije režima in širjenja ideologije socialističnega samoupravljanja si je država naivno umetnost podredila kot orodje širjenja kulturnih dobrin $\mathrm{v}$ odročne podeželske kraje in premoščanja kulturnih in družbenih razlik. Naiva je tako prešla v sfero popularne kulture. Skozi produkcijo reproduciranja dekorativnosti ter preproste likovne in pripovedne vsebine brez kompleksne ikonografije je bila posredovana izmišljena predstava družbene stvarnosti. Ta je pestro paleto različnih socialnih slojev, kultur in etnij povezala s pomočjo pastoralne in folklorne vsebine množične likovne ustvarjalnosti in njenega divjega konzumiranja. Vse je dišalo bolj

23 Na primer Wilhem Uhdeu, Krsto Hegedušić, Mića (Dimitrij) Bašević in Radoslav Putar, ki sta bila direktorja današnjega Hrvaškega muzeja naivne umetnosti, Josip Depolo, likovni kritik, Leander Brozović, oblikovalec muzeja v Koprivnici, Anatole Jakovsky, zbiralce in publicist iz Nice, ter Oto Bihalj-Merin, ki je za prepoznavnost jugoslovanske naive v svetovnem merilu naredil največ. 
po spominkarstvu in kiču kot po resnem ustvarjanju. Izgubila sta se pomen in bistvo naive, kar jo je pripeljalo do izničenja - do njenega konca.

\section{LITERATURA}

Adorno, T. W. in Horkheimer, M., The Culture Industry: Enlighment as Mass Deception (1944), v: The Consumer Society (ur. Schor, J. in Holt, D.B.), New York, 2000, str. 3-19.

Althusser, L. in drugi, Ideologija in estetski učinek, Ljubljana 1980.

Becker, H. S., Art World and Social Types, v: American Behavioral Scientist, let. 19. št. 6 July/August, 1976, str. 703-716.

Benjamin, W., Umetniško delo v času svoje tehnične reprodukcije, v: Misel o moderni umetnosti (ur. Vrečko, J.), Ljubljana 1981, str. 66-92.

Bihalj-Merin, O., Enciklopedija naivne umetnosti sveta, Beograd 1984.

Briggs, A. in Burke, P. What is the History of Popular Culture?, v: History Today, let. 35, št. 12., 1985, str. 39-41.

Crnković, V., Studije i eseji, recenzije i zapisi, interpretacije 1983-1997: Prilozi za teoriju i povjest naive i art brutističke tendencija, Zagreb 2002a.

Crnković, V., Studije i eseji, recenzije i zapisi, interpretacije 1997-2001: Prilozi za teoriju i povjest naive i art brutističke tendencija, Zagreb 2002b.

Crnković, V., Umjetnost Hlebinske škole, Zagreb 2006.

Debeljak, A., Na ruševinah modernosti; Institucija umetnosti in njene zgodovinske oblike, Ljubljana 1999.

Depolo, J., Studije i eseji, kritiki i zapisi, polemike 1954-1985: O naivi, naivima i sorodnim pojavama, Zagreb 2001a.

Depolo, J., Studije i eseji, kritiki i zapisi, polemike 1985-1999: O naivi, naivima i sorodnim pojavama, Zagreb 2001 b. 
Dolanc, S., Komunist, 11. Julij, 1971, n. p. Hemeroteka Galerije likovnih samorastnikov Trebnje, obdobje od 1968-1980.

Erjavec, A., Ideologija in umetnost modernizma, Ljubljana 1988.

Gamulin, G., Prema teoriji naivne umjetnosti; Studije i eseji, prikazi, polemike 1961-1990, Zagreb 1999.

Gartnar, J. (ur.), Svet naivnih, n. p. Trebnje 1969.

Gartnar, J. (ur.), XII. Tabor in 5. Salon likovnih samorastnikov Jugoslavije, 28. 6.-7. 7. 1979, Trebnje 1979, n. p.

Gartnar, J., Likovni samorastniki Trebnje 1968-1992: razstava ob 25-letnici mednarodnega tabora likovnih samorastnikov Trebnje, Ljubljana, 27. julij-30. avgust 1992, Cankarjev dom, Ljubljana 1992, n. p.

Gošnik, T., Umetnost - hvalnica življenja, v: 15. Tabor likovnih samorastnikov Jugoslavije (ur. Gartnar, J.), 1.-10.7.1982, Galerija likovnih samorastnikov Trebnje, n. p. Trebnje 1982.

Greenberg, C., Avantgarda in kič, v: Likovne besede, št. 47/48, 1999, str. 142-149.

Huyssen, A., After the Great Divide, Bloomington, Indianapolis 1986.

Huyssen, A., Twilight memories: making time and a culture of amnesia, New York, London 1995.

Manifest Komunističke partije i Program Saveza komunista Jugoslavije, Komitet konferencije organizacije SKJ u JNA, Split b. l., str. 290.

Matijevič, J., Otvoritveni govor na 38. Taboru likovnih samorastnikov v Trebnjem, 2005, neobj., str. 1-2., Arhiv Galerije likovnih samorastnikov Trebnje.

Neznani avtor, po Dolanc, S., Delavski razred mora biti subjekt kulture, v: Delo 1. julij 1974, n. p., Hemeroteka Galerije likovnih samorastnikov Trebnje. Obdobje 1968-1980.

Gartnar, J. (ur.), 15. Tabor likovnih samorastnikov Jugoslavije, 1.-10.7.1982, Galerija likovnih samorastnikov Trebnje, n. p., Trebnje 1982. 
Komelj, M., Galerija likovnih samorastnikov v Trebnjem, v: V objemu Temenice in Mirne; Občina Trebnje 1959-2000 (ur. Kapus, M.), Trebnje 2006.

Kržišnik, Z., Namesto uvoda, v: Salon likovnih samorastnikov Jugoslavije 7.-26. 8. 1971, Galerija likovnih samorastnikov Trebnje, n. p., Ljubljana 1971.

Kržišnik, Z., Salon likovnih samorastnikov Jugoslavije (ur. Gartnar, J.), 1.-31.7.1972, Galerija likovnih samorastnikov Trebnje, n. p., Ljubljana 1972.

Kržišnik, Z., X. tabor in VI. salon likovnih samorastnikov Jugoslavije (ur. Gartnar, J. in Kržišnik, Z.), Galerija likovnih samorastnikov Trebnje, n. p., Trebnje 1977.

Murko, M., Ne samo vzgojni pomen, v: Komunist, 21. avgust 1970, Hemeroteka Galerije likovnih samorastnikov Trebnje. Obdobje 1968-1980.

Muršič, R., Trate vaše in naše mladosti: zgodba o mladinskem rok klubu, Ceršek 2000.

Osolnik, B., Ob jubilejnem taboru, v: X. tabor in VI. salon likovnih samorastnikov Jugoslavije (ur. Gartnar, J. in Kržišnik, Z.), Galerija likovnih samorastnikov Trebnje, n. p., Trebnje 1977.

Pavlič, P. (ur.), Galerija likovnih samorastnikov Trebnje, Trebnje 2007.

Pavlovec, A. (ur.), Umetnost slovenskih samorastnikov, Tabor likovnih samorastnikov 29. 6.-18.8.1973, Galerija likovnih samorastnikov Trebnje, n. p., Trebnje 1973.

Poli, F., The Europe of the Naif Masters, v: Da Rousseau a Ligabue. Naif? (Zanasi, G., ur.), 6. september-24. november 2002, Palazzo Bricherasio, Torino, Milano 2002, str. 182-183.

Režun, M., Ali so slovenski naivci res naivni?, v: Rast, Revija za literaturo, kulturo in družbena vprašanja, let. 3, 1991, str. 266-274.

Storey, J., Inventing Popular Culture: From Folklore to Globalization, Oxford 2003. 
Smiljković, K. (ur.), Titovo delo, vreme u stvaralištvu samoukih likovnih umetnika Svetozarevo, Svetozarevo 1980.

Smith D. A., National Identity, Reno, Las Vegas, London 1991.

Smith D. A., Nacionalizem; Teorija, ideologija, zgodovina, Ljubljana 2005.

Štepec, D., Tabor likovnih samorastnikov v Trebnjem, neobj., seminarska naloga B, Oddelek za umetnostno zgodovino, Filozofska fakulteta Univerze v Ljubljani, Ljubljana 1997.

Tršar, M., Kriteriji za presojo umetniške kvalitete »samorastnikov«, v: Sodobnost, let. 13, št. 1, 1970, str. 84-87.

Tršar, M., Tisnikar, Ljubljana 1973.

Zander, C., Consideration on Naive Art, v: Da Rousseau a Ligabue. Naif? (Zanasi, G., ur.), 6. september-24. november 2002, Palazzo Bricherasio, Torino, Milano 2002, str. 184-185.

\section{VIRI}

Hemeroteka Galerije likovnih samorastnikov Trebnje. Obdobje 19681980.

Arhiv Galerije likovnih samorastnikov Trebnje.

Tonski zapis okrogle mize Naivna umetnost in Galerija likovnih samorastnikov Trebnje danes februarja 2008. Arhiv Galerije Likovnih samorastnikov Trebnje.

Tonski zapis slavnostnega govora Zorana Kržišnika na zaključku 41. Tabora likovnih samorastnikov Trebnje, junij 2008. Arhiv Galerije Likovnih samorastnikov Trebnje. 


\title{
YUGOSLAV NAIVE ART AND POPULAR CULTURE
}

Keywords: Yugoslav Naive Art, popular culture, Trebnje Naive Artists' Camp, Yugoslavia, ideology

\begin{abstract}
Naive art in Yugoslavia was not only an artistic phenomenon, but also a cultural and a social phenomenon that has grown into a form of popular culture. Using the example of the Trebnje Naive Artists' Camp, it is argued that artistic creativity transcended the sphere of art and was shifted into popular culture through vigorous and large-scale production, reproduction, and commercialization of the artworks, and by a media and journalistic coverage of naive artists and the events related to naive art. However, without the support and Direction of the cultural policy of a socialist state, this would not have been possible.

The term "naive art" was finally established in the 1950s and was applied to the art practiced by self-taught artists (mainly painters and less often sculptors), who often came from marginal backgrounds. Nonetheless, their talent was noticed by some art collectors, critics, and already established artists, as was the case in France or in Yugoslavia. Naive artists expressed themselves in a simplified form with figurative and narrative motifs related to their inner or outer world or local visual tradition. The masters of naive art were part of modern art and some avant-garde movements, exemplifying how no educated person from a marginal environment could attain a high aesthetic value and strong creative expression. Furthermore, after the Second World War naive art become quite popular among the general public in Europe and the rest of the world, yet this was also the time of its decline. Naive art in Yugoslavia and especially the Hlebine school may be considered the last phase in historic European naive art.

After the Second World War, the Yugoslav socialist state also strove to equalize and democratize society through art by minimizing the differences between the producers and consumers of art. Such a policy led to the decentralization of culture by forming various cultural and artistic institu-
\end{abstract}


tions and by holding cultural events and spectacles in the countryside and peripheral areas. Through these various informal ideological mechanisms, the state apparatus exercised its authority in socializing its people in the spirit of Yugoslav socialist self-management and the ideology of brotherhood and unity by joining together the producers and consumers of naive art from various ethnicities, cultures, and social classes. Unfortunately this transformed naive art at its peak of popularity into a decorative and souvenir artifact with a pastoral image and folklore motifs. The encouragement from the authorities on the one hand and the market on the other produced and reproduced simple art forms and narrative contents without a complex iconography, which were consumed uncritically and on a large scale. Consequently, this completely denied the core of naive art and resulted in its final devaluation. 